\title{
H-FARM: The Innovation Hub*
}

\author{
Marco Pavan ${ }^{* *}$, Marzia Giuditta Anelli***
}

\begin{abstract}
This paper has the goal to describe the structure and the features of H-FARM. After more than ten years of activity H-FARM has developed an innovative platform in Roncade (TV) that has the ambitious goal of creating an ecosystem where students, corporates and digital start-ups are working together contaminating each other. The company approach towards the start-up ecosystem is led by a special acceleration method that makes H-FARM a unique platform.
\end{abstract}

Keywords: Accelerator; Start-Up; Entrepreneur; Education; Digital; Global Markets; Innovation

\section{H-FARM: History and Structure}

H-FARM is an innovative platform that supports the creation of new business models through investments in start-ups, driving the transformation of big corporates in a digital perspective and providing high-level digital education to students and professionals.

H-FARM was founded in January 2005 and is the first global initiative that links seed-stage venture capital investments and business acceleration services with a specific focus on digital businesses.

H-FARM supports young people and companies in their digital training and specifically guides companies towards their digital transformation, with the goal of creating value and developing an innovative ecosystem.

The " $\mathrm{H}$ " stands for Human, which underlines the first objective of developing initiatives and rendering their operation simpler. The concept also extends to those working on the project. Ultimately, the project aims to transform inventions into innovations, ideas into products and people into entrepreneurs. H-FARM's vision for the next ten years concerns three main stakeholders: young people, the territory and corporates. H-FARM will work closely with the new generation to facilitate such transformations, start-ups and education with the intention of generating awareness and responsibility, two notions that are extremely important in $\mathrm{H}$ FARM's overall conception.

The awareness of students is fostered through the education path provided at the

\footnotetext{
* Invited Article

** Venture Analyst and Head of Scouting, H-FARM (marco.pavan@h-farm.com)

*** Venture Analyst and Program Manager, H-FARM (marzia.anelli@h-farm.com)
} 
H-CAMPUS. One of the main objectives of the new education business unit is to provide young students with the tools to exploit and seize all the opportunities engendered by the digital revolution to enable them to become key players in tomorrow's work system.

For companies involved in H-FARM, the objective is to provide them with the tools that allow them to face the digital transformation that each field or sector is undergoing.

H-FARM's business model is built on three main pillars:

1) H-FARM Industry;

2) H-FARM Education;

3) H-FARM Investments.

1) The main objective of the Industry business unit is to become the first "new generation" consulting company in Europe. The BU works to help entrepreneurs and business leaders to transform their companies facing disruption, redefining companies' approach towards innovation. (The industry business unit has as main objective to become the first "new generation" consulting company in Europe, this is to say that through the redefinition of business' approach to innovation H-FARM wants to help entrepreneurs and business leaders transform their companies facing disruption.) Moreover, the goal is to understand and act on technology changes, being active players of the new industrial revolution. In other words, H-FARM helps enterprises to transform and innovate their business models and operations, while embracing the digital changes.

2) The education project is very ambitious and unique: the traditional education systems are quickly becoming obsolete, for this reason demand for innovation learning methods is rapidly increasing, H-FARM wants to build an education path that is able to develop the most brilliant minds in Italy's largest digital ecosystem, by integrating best in class academic standards with new learning methods, business, best practice and start-up opportunities.

3) H-FARM Investments is the division that will deepen in the following paragraphs and it is divide in 2 areas: H-FARM Accelerator and H-FARM Fund.

\section{H-FARM Investments: The Accelerator and the VC Model}

When Riccardo Donadon founded H-FARM in 2005, his first objective was to do a "giving-back" operation.. His first two companies went were so successful that he wanted to help young people to become entrepreneurs. The very first activity of $\mathrm{H}$ FARM was to sustain start-ups; this wasn't an easy activity as it wasn't usual and a real acceleration program scheme didn't exist at time. Riccardo Donadon and his staff decided to try different experiments, the first two companies H-FARM funded were H-CARE and H-ART that eventually became also its first exits. At the beginning of the acceleration activities the concept behind it was simple: H-FARM 's mission was to seed, grow and take care of the companies that were selected.

After the first years H-FARM started to define two different ways to develop and support innovative ventures on the Italian market: on one side the Accelerator Model that has the aim to select and invest in innovative projects and start-ups in 
order to help them to build and test their business models; on the other side the VC Model, the activity of investing in either the best start-ups that are accelerated through the H-FARM Accelerator Program or in early-stage Italian and European start-ups with global ambitions within the fields of SaaS, consumer internet, and B2B services.

\section{The Accelerator Model}

Through the years H-FARM has developed a unique and strong acceleration method on which the work of every acceleration program is based. The whole acceleration process is divided in three main phases:

1. Scouting \& Selection;

2. Acceleration Program;

3. Fundraising.

Figure 1: The Accelerator Process

\begin{tabular}{|c|c|c|}
\hline 3 months & 3 months & 1 month \\
\hline $\begin{array}{l}\text { SCOUTING \& } \\
\text { SELECTION }\end{array}$ & $\begin{array}{l}\text { ACCELERATION } \\
\text { PROGRAM }\end{array}$ & $\begin{array}{l}\text { FUND- } \\
\text { RAISING }\end{array}$ \\
\hline $\begin{array}{l}\text { Promotion activities } \\
\text { aimed to find the best } \\
\text { target projects. } \\
\text { Applicants screening and } \\
\text { selection of the winners }\end{array}$ & $\begin{array}{l}\text { Acceleration of the chosen startups } \\
\text { through a series of high-value services } \\
\text { (e.g. mentorship, workshops, biz } \\
\text { network, room\&board, ...) and Cash } \\
\text { investment }\end{array}$ & $\begin{array}{c}\text { Final event (and month) } \\
\text { dedicated to present the } \\
\text { startups to a selected network } \\
\text { of VC Funds, Biz Angels and } \\
\text { Corporate Investors }\end{array}$ \\
\hline
\end{tabular}

In the first phase the main stakeholders are the Accelerator Director and the acceleration team, these have the task to define the strategy for the upcoming call for ideas, to define the brief and to prepare the activities plan.

In this process is also involved the Communication team which is in charge of preparing and taking care of all the marketing and communication activities

The whole call for ideas and selection process lasts about three months and the team's main objective is to attract the best start-ups in Europe and in the world. Moreover, what's important for the scouting process is to select start-ups that fit both with the brief and with H-FARM vision and environment. Likewise, it is important for the acceleration team to set the right criteria and deeply analyze every application. To that end, the call manager goes beyond the form of application and tries to arrange Follow up calls to either support the teams in the application process, or to ask them some explanations about the form.

The last step of this phase is the OPEN DAY: an event that sees 20 to 30 best applicants visiting H-FARM and pitching their project to the investment committee.

This event is very useful for both start-ups and the acceleration team; the former 
have the chance to visit H-FARM and ask questions and the latter can get to know better the teams investigating every aspect of their projects and of the team components. Every program lasts 4 months: the first three are dedicated to the strategy definition and to the development of the product and the last one is entirely focused on fundraising. The program is structured in a way that each start-up just need to focus on its project without worrying about anything else.

H-CAMP is one of the few programs in the world to offer an all inclusive solution to all the accepted start-ups, this means that up to 4 people per team will have access to all H-FARM's services and facilities, including food and accommodation.

Among all this, the real added value of H-FARM's acceleration program is the access to a world class network of entrepreneurs, corporations, investors and experts. Thanks to the experience of the partners and thanks to the ecosystem that has been developed by H-FARM, H-CAMP's start-ups have the chance to get in touch with a lot of stakeholders that can help them both with their business development and with the fundraising phase. Through the months the start-ups will be asked to follow workshops and mentoring sessions, and mostly to work closely with the Accelerator Team in order to define each aspect of the development.

Each month of the acceleration program is structured in a way that gives the opportunity to all the start-ups to follow a specific growth path.

The first month is entirely dedicated to Business and Strategy, the start-ups will focus on building a strong strategy beginning from a convincing Business Model Canvas and Pitch Deck.

Workshops and mentoring session of the second month will have as main topic the product development. This phase is crucial as each team will investigate and, at least, design all the aspect of the product.

The third month's core topic is Sales and Marketing: approaching the demo night and the end of the program each start-up is designing a marketing matrix and a business roadmap helped by mentors of specific industrial sectors.

The fourth, and last, month of the program is entirely dedicated to fundraising. Searching for new investments is what drives daily activities during this last period. At this end the teams needs to work closely with the program manager in order to point out possible interested investors, furthermore they need to develop an investor strategy meaning that the start-up should plan an ad hoc approach to the fundraising period.

Beyond a doubt, a key moment of the acceleration program is the DEMO NIGHT: the final event where start-ups pitch to an audience of investors, entrepreneurs and possible partners.

During the last month of the acceleration program start-ups spend most of their energies to get to this final event at the best condition, to this end they need to be ready with a "kick ass" pitch, the right attitude and a great product.

The demo night is a great opportunity to all the start-ups to open contacts, partnerships and to meet investors.

At the end of the program H-FARM may do a further investment in some of the teams; yet these are not VC investment but they need to be seen as bridge investments that give start-ups the chance to take time and search for biggest and further investments without having cash flows issues. In this way the teams that receive an investment can keep on developing the product while looking for 
investors.

\section{Accelerator Model for Corporates}

H-FARM wants to partner leading Corporates with start-ups trough its services: this relationship has unequaled mutual benefits for both parties - cash and new exit paths for start-ups and growth opportunities for large organizations.

The objective is to propose to the client Companies a new collaborative model for pursuing innovation and managing investment activities. In doing this, H-FARM offers a plurennial experience of scouting, supporting and investing in promising new ventures, structured in H-FARM Accelerator \& Scouting Method (see previous paragraph). In addition to that, Donadon's company can leverage of its International Start-up Network in order to increase the value of the services, having access to additional and exclusive resources.

H-FARM believes that start-ups that partner with corporates and VC disruptors are uniquely positioned to prosper in a more restrictive investment climate. One of the most interesting solutions that H-FARM offers to Companies is the Corporate Accelerator Program, an innovative solution to enhance corporate venture capital projects. Corporate Venture Capital (CVC) is the practice where a large firm takes an equity stake in a small but innovative or specialist firm, to which it may also provide management and marketing expertise; the objective is to gain a specific competitive advantage.

"Large companies have long sensed the potential value of investing in external start-ups. More often than not, though, they just can't seem to get it right" (from Making Sense of Corporate Venture Capital written by Henry W. Chesbrough, Harvard University).

H-FARM wants to be the right partner for Companies willing to innovate, establishing a structured program with the aim to find digital start-ups, select the best and accelerate their business. Corporate Accelerator is a full-service 4-month program dedicated to selected early stage start-ups operating in specific industries defined by the Company. Start-ups can apply to the program during the "Call For Ideas", a specific time ( 8 weeks), set for receiving applications and for promoting the initiative. In the context of this program, experienced mentors, experts and an H-FARM dedicated team spend four months helping start-ups to advance their business. At the end of the program the Company can take an equity stake on the accelerated start-ups and also proceed with a further investment or establish partnerships or specific agreements/collaborations.

There are some unique benefits for Companies that launch Corporate Accelerator Programs:

- M\&A and Investment Opportunity: possibility to take an equity stake on each start-up accelerated and proceed with a second investment round or acquire the start-ups

- New Markets \& Business: Company will get innovative ideas in order to improve their own business or exploit new markets

- Process Innovation \& New Tools: Companies will have the opportunity to collaborate and integrate with start-ups' solutions useful to improve and change 
internal process and methods

- Talent Acquisition: Company will gain access to hundreds of innovative ventures composed by high-skilled people in design, code development and business/marketing

- Branding: Corporate Accelerator will increase the brand values and awareness for external stakeholders and internal stakeholders

The first Company that has partnered with H-FARM in launching a Corporate Accelerator was Technogym, the world leader in the fitness and wellness industry with Wellness Accelerator Program (www.wellnessaccelerator.com)

The Wellness Accelerator is a program powered by Technogym and managed by H-FARM, dedicated to scouting, selecting and growing 5 digital start-ups operating in the fitness and wellness industry.

Wellness Accelerator has generated interest and press at an international level, attracting start-ups from all around the world. In two editions, more than 450 startups submit their project and Technogym, together with H-FARM, selected and accelerated 11 start-ups. The two programs have given to Technogym the opportunity to collaborate with and invest in start-ups operating in new and emerging markets/sectors such as corporate wellness, personal training platforms, fitness gamification and social solutions.

On January 2016, H-FARM has renovated the collaboration with Technogym for a third edition of the Wellness Accelerator and currently is working with other large enterprises for launching new Corporate Accelerator Programs in 2017.

\section{The VC Model}

H-FARM is pursuing two strategies, one is pursued by the Accelerator and the other by InReach Ventures. H-FARM has recently entered into an investment agreement to widen H-FARM's Investment business unit at a European Level by acquiring a minority stake in InReach Ventures LLP a "next generation" venture firm founded in 2015 by Roberto Bonanzinga, John Mesrie and Ben Smith.

The first strategy is to invest in early-stage start-ups with national or global ambitions on the field of SaaS, consumer internet, and B2B services. The latter uses a different method: InReach Data Limited intends to develop an advanced Software as a Service (SaaS) layer to disrupt the traditional Venture Capital investment model and solve the lack of scalability of such labour intensive model. The purpose of InReach Data Limited, through the SaaS, is to develop automation across many aspects of the venture Capital Value-chain with specific emphasis on three areas: automated deal flow generation, deal syndication and portfolio community.

This new partnership renovates the VC business of H-FARM: since the 2005 the Company has invested seed money in Italian and European start-ups, focusing in particular on follow-on investments on the best project that are accelerated by the H-FARM Accelerator. 


\section{Conclusion}

After analysing H-FARM activities and relationships with start-ups, it is possible to affirm that its approach is extremely innovative within the Italian and European system. The unique approach of involving education, corporates and start-ups in the same project creating an impactful ecosystem could be considered as a case study of a different approach towards the support and acceleration of start-ups. These are immerse in an environment that is not made by tech lovers, investors and entrepreneurs only but also by students, companies and other stakeholders that could help with the development of start-ups; most of all these players bring a lot of added value when it comes at mixing lot of different know how and a general diversity that can contribute effectively in start-ups strategies and business.

\section{Bibliography}

Arranz, N., \& de Arroyabe, J. C. F. (2008). The choice of partners in R\&D cooperation: An empirical analysis of Spanish firms. Technovation, 28(1), 88-100. http://dx.doi.org/10.1016/j.technovation.2007.07.006

Arrigo, E. (2012). Alliances, Open Innovation and Outside-in Management, Symphonya. Emerging Issues in Management (symphonya.unimib.it), 2, 53-65

http://dx.doi.org/10.4468/2012.2.05arrigo

Berger, A., \& Brem, A. (2016). Innovation Hub How $\square$ To: Lessons From Silicon Valley. Global Business and Organizational Excellence, 35(5), 58-70.

Brondoni, S.M. (2012). Innovation and Imitation: Corporate Strategies for Global Competition, Symphonya. Emerging Issues in Management (symphonya.unimib.it), 1, 10-24

http://dx.doi.org/10.4468/2012.1.02brondoni

Brondoni, S.M. (2013). Ouverture de 'Global Networks and Local Development-2', Symphonya. Emerging Issues in Management (symphonya.unimib.it), 2, 1-18 http://dx.doi.org/10.4468/2013.2.010uverture

Gnecchi, F. (2004). Relations between Local Authorities and Public Utilities Companies, Symphonya. Emerging Issues in Management (symphonya.unimib.it), 1, 58-68 http://dx.doi.org/10.4468/2004.1.06gnecchi

Knight, J. (2015). Regional Education Hubs--Rhetoric or Reality. International Higher Education, (59).

Leonardi, P., \& Bailey, D. (2016). Recognizing and selling good ideas: network articulation and the making of an offshore innovation hub. Academy of Management Discoveries, amd-2015.

Longo, M. C., Giaccone, S. C., \& Garraffo, F. (2013). Applying the hub-and-spoke model to virtual communities: the IBM innovation approach. International Journal of Technology Marketing 24, 8(2), 142-158.

Oksanen, K., \& Hautamäki, A. (2014). Transforming regions into innovation ecosystems: A model for renewing local industrial structures. The Innovation Journal, 19(2), 1.

Riboldazzi, S. (2015). R\&D and Product Engeneering in Global Pharmaceutical Companies, Symphonya. Emerging Issues in Management (symphonya.unimib.it), 2, 57-74

http://dx.doi.org/10.4468/2015.2.05riboldazzi

Rieple, A., Pironti, M., Pisano, P. (2012). Business Network Dynamics and Diffusion of Innovation, Symphonya. Emerging Issues in Management (symphonya.unimib.it), 2, 13-25 http://dx.doi.org/10.4468/2012.2.02rieple.pironti.pisano 